Available online at: http://e-journal.upstegal.ac.id/index.php/jip

Submission: 31-07-2017; Revision: 26-02-2018; Publish: 30-05-2018

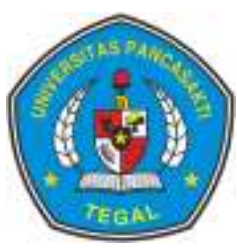

DOI: http://dx.doi.org/10.24905/jip.v3i1.710

\title{
Pembangunan dan Mekanisme Sistem Perencanaan (Studi Kasus Desa Pengabean dan Desa Karanganyar)
}

\author{
Arif Zainudin 1) *, Sri Sutjiatmi 2) \\ 1,2 Program Studi Ilmu Pemerintahan, Universitas Pancasakti Tegal. Jalan Halmahera Km. 1, Kota Tegal, \\ Jawa Tengah, 53121 Indonesia. \\ * Korespondensi Penulis. E-mail: arifzainudin@upstegal.ac.id, Telp: +6287730994000
}

\begin{abstract}
Abstrak
Pemerintahan desa adalah organisasi tingkat dasar untuk melayani kebutuhan masyarakat di daerah tertentu. Dengan Undang-Undang Nomor 6 Tahun 2014 Tentang desa, diberi wewenang untuk mengurus rumah tangga (pemerintah desa) secara mandiri. Peraturan tersebut tidak hanya memberikan otonomi namun secara sewenang-wenang menambah sumber pendapatan Desa. Sumber pendapatan desa dibagi menjadi tiga klasifikasi yang berasal dari anggaran negara, anggaran, dan pengelolaan aset desa. Dengan sumber pendapatan yang dapat mengembangkan desa, pemerintah desa harus bisa merencanakan program kerja yang ditargetkan dan terukur. Program ini direncanakan melalui dokumen perencanaan pembangunan desa seperti RPJMDes, RKPDes, dan APBDes. Seperti kasus seperti Desa Karanganyar dan Desa Pengabean, desa tersebut tidak memiliki dokumen rencana pembangunan desa. Karena menurut PP 43 tahun 2014 tentang Peraturan Pelaksana Undang-Undang Nomor 62014 tentang Desa, menyebutkan bahwa pencairan dana desa harus memiliki dokumen perencanaan. Dengan uraian masalah tersebut, penulis membatasi pokok bahasan tentang model perencanaan pembangunan desa Karanganyar dan Pengabean. Berdasarkan permasalahan tersebut peneliti melakukan desain siklus perencanaan yang sesuai dengan tipologi masyarakat desa. Desain pengembangan model perencanaan menggunakan pendekatan metode R\&D (Penelitian dan Pengembangan) dengan mempertimbangkan perilaku masyrakat.
\end{abstract}

Kata Kunci: Perencanaan Pembangunan; Desa.

\section{Development and Mechanism of Planning System (Case Study in Pengabean Village and Karangannyar Village)}

\begin{abstract}
Village governance is a basic level organization to serve the needs of people in certain areas. By Law Number 6 Year 2014 About the village, it is authorized to take care of the household (village government) independently. The regulation not only grants autonomy but arbitrarily adds to the village's revenue source. The source of village income is divided into three classifications derived from the state budget, budget, and management of village assets. With a source of income that can develop villages, village governments should be able to plan targeted and measurable work programs. The program is planned through village development planning documents such as RPJMDes, RKPDes, and APBDes. As in the case of Karanganyar and Pengabean Villages, the village has no document of village development plan. Because according to PP 43 of 2014 on the Implementing Regulation of Law No. 62014 on the Village, states that the disbursement of village funds should have a planning document. With the description of the problem, the authors limit the subject of the Karanganyar village development planning model and Pengabean. Based on the problem, the researcher design the planning cycle according to the typology of the village community. Design of planning model development using approach of $R \& D$ method (Research and Development) by considering behavior of society.
\end{abstract}

Keywords: Development Planning; Village. 
Arif Zainudin ${ }^{1)}{ }^{*}$, Sri Sutjiatmi ${ }^{2)}$

\section{PENDAHULUAN}

Pemerintah Desa merupakan penyelenggaraan urusan pemerintahan dan kepentingan masyarkat setempat dalam sistem pemerintahan Negara Kesatuan Republik Indonesia, dalam aktifitasnya pemerintahan desa menjalankan fungsi tata kelola yakni perencanaan pembangunan. (Zainudin, 2016). Perencanaan sebagai suatu proses yang berkesinambungan yang mencakup keputusan dan pilihan berbagai alternative sumber daya untuk mencapai tujuan tertentu pada masa yang akan datang(Hadi, Hakim, \& Noor, 2014). Fungsi tersebut mutlak ada dalam suatu organisasi formal dan non formal karena perencanaan adalah pemikiran hari depan Desa(Nugroho, 2010).

Dalam melakukan perencanaan Desa hendaknya memperhatikan prinsip-prinsip perencanaan pembangunan seperti yang tertuang dalam Undang-Undang No. 25 tahun 2004 tentang Sistem Perencanaan Pembangunan Nasional (Mayasari, 2014).

Melihat fungsi manajemen pemerintah yang telah diuraikan sebelumnya sangat sesuai dengan amanah Undang-Undang No. 6 tahun 2014 tentang Desa, pasal 78 ayat 1 menerangkan bahwa pembangunan Desa meliputi tahapan perencanaan. Oleh karena itu perencanaan pembangunan Desa harus memperhatikan pada dokumen perencanaan pembangunan Kabupaten/Kota. Setelah dokumen perencanaan pembangunan desa telah disepakati diharapkan dapat menimbulkan dampak yang positif untuk masyarakat Desa dan kebutuhan pelayanan masyarakat Desa segera terpenuhi.

Terkait dalam perencanaan pembangunan Desa berdasarkan UndangUndang No. 6 Tahun 2014 tentang Desa, dokumen perencanaan pembangunan desa meliputi Rencana Pembangunan Jangka Menengah Desa (RPJM) yang masa berlakunya yakni 6 (enam) tahun, Rencana Kerja Pemerintah Desa (RKPDes) yang masa berlakunya 1 (satu) tahun, dan Anggaran Pendapatan Belanja Desa (APBDes) dokumen tersebut merupakan acuan perencanaan pembangunan Desa. Dengan adanya dokumen perencanaan pembangunan Desa, diharapkan proses pembangunan dan pelaksanaan pembangunan Desa lebih terfokus kepada permasalahan masyarakat. Kendala yang dihadapi dalam proses perencanaan pembangunan yakni kearifan lokal desa tidak tercantum dalam dokumen perencanaan desa (Hilman, 2017). Namun menurut (Deviyanti, 2013) kendala yang menjadi faktor penghambat dalam perencanaan pembangunan yakni partisipasi masyarakat desa yang menjadi pemikir pembangunan.

Tujuan penelitian ini untuk menentukan model perencanaan pembangunan desa yang dapat digunakan melibatkan partisipasi masyarakat.

\section{Partisipasi Masyarakat dalam Perencanaan}

Partisipasi diartikan sebagai "keikutsertaan", "keterliatan" dan "pembagian peran". Konsep partisipasi 


\section{Jurnal Ilmu Pemerintahan: Kajian Ilmu Pemerintahan dan Politik Daerah, Vol 3 (1), April 2018 - 3}

Arif Zainudin 1) *, Sri Sutjiatmi ${ }^{2)}$

telah lama menjadi bahan kajian (Raharjana, 2012). Dalam pembangunan paritisipasi berarti usaha yang terorganisir dari berbagai pihak (perempuan dan laki-laki) (Narutomo, 2014).

Dengan demikian, konsep partisipasi merupakan serangkaian kegiatan yang sitematis dan tersturktur dengan melibatkan masyarakat untuk mengambil inisiatif, pengambilan keputusan, menetapkan arah dan tujuan, perencanaan, pelaksanaan, pengorganisasian, dan mengevaluasi dengan mengoptimalkan potensi dan kemampuan yang ada padanya.

Bentuk partisipasi menurut (Fogg, 1994) menguraikan bentuk partisipasi yang dilihat dalam beberapa cara yaitu 1) konsultasi, biasanya dalam bentuk jasa; 2) sumbangan spontan dalam bentuk uang atau/dan barang; 3) mendirikan proyek yang bersifat berdikari dan donornya berasal dari sumbangan individu, instansi yang berada diluar lingkungan tertentu; 4) mendirikan proyek yang bersifat berdikari dan dibiayai seluruhnya oleh masyarakat (biasanya diputuskan oleh rapat komunitas, antara lain rapat desa dalam menentukan anggaranyan; 5) sumbangan dalam bentuk kerja, yang biasayanya dilakukan oleh tenaga ahli setempat; 6) aksi massa; 8) mengadakan pembangunan di kalangan keluarga desa sendiri.

(Planners, 1969:216) berpendapat bahwa partisipasi masyarakat dapat disimulasikan sebagai distribusi kekuasaaan antara anggota masyarakat dengan pemerintah lokal. Kemudian (Arnstein, 1969) mengidentifikasi partisipasi masayrakat merupakan kekuasaan. Partisipasi masyarakat bertingkat sesuai dengan gradasi kekuasaan yang dapat dilihat dalam proses pengambilan keputusan atau kebijakan. Seperti tabel 1 Arnstein berpendapat tentang level partisipasi masayrakat.

Tabel 1. Tingkat Partisipasi Masyarakat

\begin{tabular}{|c|c|c|c|}
\hline No. & $\begin{array}{c}\text { Tingkat } \\
\text { Partisipasi }\end{array}$ & $\begin{array}{c}\text { Hakekat } \\
\text { Kesetaraan }\end{array}$ & $\begin{array}{c}\text { Tingkatan } \\
\text { Pembagian } \\
\text { Kekuasaan }\end{array}$ \\
\hline 1. & Manipulasi & $\begin{array}{l}\text { Permainan oleh } \\
\text { Pemerintah }\end{array}$ & \\
\hline 2. & Terapi & $\begin{array}{l}\text { Sekedar agar } \\
\text { masyarakat tidak } \\
\text { marah/ } \\
\text { sosialisasi }\end{array}$ & $\begin{array}{l}\text { Tidak ada } \\
\text { partisipasi }\end{array}$ \\
\hline 3. & $\begin{array}{l}\text { Pemberitah } \\
\text { uan }\end{array}$ & $\begin{array}{l}\text { Sekedar } \\
\text { pemberitahuan } \\
\text { searah/ } \\
\text { sosialisasi }\end{array}$ & \\
\hline 4. & Konsultasi & $\begin{array}{l}\text { Masyarakat } \\
\text { didengar, tapi } \\
\text { tidak selalu } \\
\text { dipakai sarannya }\end{array}$ & $\begin{array}{l}\text { Tokenism/ } \\
\text { sekedar } \\
\text { penilaian } \\
\text { agar }\end{array}$ \\
\hline 5. & $\begin{array}{l}\text { Penentrama } \\
\mathrm{n} \\
\text { (placation) }\end{array}$ & $\begin{array}{l}\text { Saran } \\
\text { masyarakat } \\
\text { diterima tapi } \\
\text { tidak selalu } \\
\text { dilaksanakan }\end{array}$ & mengiyakan \\
\hline 6. & $\begin{array}{l}\text { Kemitraan } \\
\text { (Partnershi } \\
\text { p) }\end{array}$ & $\begin{array}{l}\text { Timbal balik } \\
\text { dinegosiasikan }\end{array}$ & \\
\hline 7. & $\begin{array}{l}\text { Pendelegasi } \\
\text { an } \\
\text { kekuasaan } \\
\text { (Delegated } \\
\text { Power) }\end{array}$ & $\begin{array}{l}\text { Masyarakat } \\
\text { diberi kekuasaan } \\
\text { (Sebagian atau } \\
\text { seluruh } \\
\text { program) }\end{array}$ & $\begin{array}{c}\text { Tingkat } \\
\text { kekuasaan } \\
\text { ada di } \\
\text { masyarakat }\end{array}$ \\
\hline 8. & $\begin{array}{l}\text { Kontrol } \\
\text { Masyarakat }\end{array}$ & $\begin{array}{l}\text { Sepenuhnya } \\
\text { dikuasai oleh } \\
\text { masyarakat }\end{array}$ & \\
\hline
\end{tabular}

\section{Perencanaan Pembangunan Desa}

Desa menurut (Zakaria \& Suprihardjo, 2014) mendefinisikan sebagai komunitas kecil yang menetap di suatu daerah, dan mendefinisikan desa sebagai setiap pemukiman para petani. Indonesia penggunaan istilah tersebut digunakan dengan cara yang berbeda untuk masing-masing daerah, seperti dusun bagi maysarakat Sumatera 


\section{Jurnal Ilmu Pemerintahan: Kajian Ilmu Pemerintahan dan Politik Daerah, Vol. 3 (1), April 2018 - 4}

Arif Zainudin ${ }^{1)}$, Sri Sutjiatmi ${ }^{2)}$

Selatan, Dati bagi Maluku, kuta untuk Batak, Nagari untuk Sumatera Barat, atau wanua di Minahasa. Bagi masyarakat lain desa memiliki keunikan tersendiri dan berkaitan erat dengan mata pencaharian, norma, dan adat istiadat yang berlaku.

Sedangkan (Fauzi \& Zakaria, 2000) menyatakan, Desa adalah sekumpulan manusia yang hidup bersama dalam suatu wilayah, yang memiliki suatu organisasi pemerintahan, dengan serangkaian peraturan-peraturan yang ditetapkan sendiri, serta berada di bawah pimpinan desa yang dipilih dan ditetapkan sendiri. Definisi ini, menegaskan bahwa desa sebagai satu unit kelembagaan pemerintahan mempunyai kewenangan pengelolaan wilayah perdesaan. Wilayah pedesaan sendiri diartikan sebagai wilayah yang penduduknya mempunyai kegiatan utama pertanian, termasuk pengelolaan sumberdaya alam, dengan susunan fungsi wilayah sebagai pemukiman perdesaan, pelayanan jasa pemerintah, pelayanan sosial, dan kegiatan ekonomi. Dalam mewujudkan fungsi wilayah maka, Desa menerapkan tata kelola atau manajemen pembangunan Desa.

Pembangunan Desa dilakukan dengan tujuan meningkatkan kesejahteraan masyarakat Desa dan kualitas hidup manusia serta penanggulangan kemiskinan melalui pemenuhan kebutuhan dasar, pembangunan sarana dan prasaran Desa, pengembangan potensi ekonomi lokal, serta pemanfaatan sumber daya alam dan lingkungan secara berkelanjutan (Bachrein, 2016).
Berdasarkan Undang-Undang No. 6 Tahun 2014 tentang Desa, pasal 78 dalam rangka melaksanakan pembangunan maka tahapan pertama yakni perencanaan.

Dalam menyusun perencanaan pembangunan Desa dapat disesuaikan dengan kewenangan Desa dengan mengacu pada perencanaan pembangunan Kabupaten /Kota.

Melaksanakan perencanaan pembangunan desa lebih terdapat 2 (dua) pendekatan yakni Pertama, Pendekatan bottom-up yang mempunyai makna perencanaan yang dilakukan atau yang diusulkan dari masyarakat tingkat bawah atau lebih mengutamakan partisipasi masyarakat Desa dalam menentukan program kerja Desa. Kedua, Pendekatan Teknokratik yang memiliki arti bahwa perencanaan pembangunan disusun oleh lembaga/orang yang memahami tentang penyusunan dokumen perencanaan pembangunan Desa. Pendekatan ini digunakan sebagai pelaksanaan fungsi kelembagaan Desa (Rustiadi, Saefulhakim, \& Panuju, 2009).

Adapun kriteria perumusan perencanaan pembangunan Desa menurut (Sumenge, 2013) terbagi berdasarkan kategori kebutuhan masyarakat Desa, yang meliputi:

a. Peningkatan kualitas dan akses terhadap pelayanan dasar;

b. Pembangunan dan pemeliharaan infrastruktur dan lingkungan berdasarkan kemampuan teknis dan sumber daya lokal yang tersedia;

c. Pengembangan ekonomi pertanian berskala produktif; 
Jurnal Ilmu Pemerintahan: Kajian Ilmu Pemerintahan dan Politik Daerah,

Vol 3 (1), April 2018 - 5

Arif Zainudin ${ }^{1)}$, Sri Sutjiatmi ${ }^{2)}$

d. Pengembangan dan pemanfaatan teknologi tepat guna untuk kemajuan ekonomi; dan

e. Peningkatan kualitas ketertiban dan ketentraman masyarakat Desa berdasarkan kebutuhan masyarakat Desa.

Dalam melakukan perencanaan pembangunan di Desa Karanganyar dan Desa Pengabean Kabupaten Tegal, lebih mengutamakan musyawarah Desa yang melibatkan masyarakat Desa beserta para tokoh masyarakat Desa. Materi pembahasan pada musyawarah Desa (MusrenbangDes) membahas mengenai program, kegiatan dan kebutuhan pembangunan, yang kemuian ditetapkan prioritas arah pembangunan Desa. Berdasarkan klasifikasi (Planners, 1969)

\section{METODE}

Penelitian ini menggunakan metode kualitatif, dimana desa yang diteliti sebagai objek alami dan peneliti sebagai instrumen kunci (Sugiyono, 2009). Kemudian untuk teknik pengumpulan data dilakukan secara triangulasi, sedangkan data yang dihasilkan bersifat deskripsi dan analisis data dilakukan secara induktif. Hasil penelitian kualitatif lebih mengedepankan makna atau hasil yang diteliti.

Pendekatan penelitian ini melalui desain riset evaluasi perencanaan pembangunan desa, dengan melakukan evaluasi pada dua desa yakni Desa Pengabean dan Desa Karanganyar Kabupaten Tegal.
Desain penelitian dibangun berdasarkan model evaluasi CIPP (Context Input Process Product) yang diterapkan dalam sistem pemerintahan (Narutomo, 2014)

\section{HASIL DAN PEMBAHASAN}

Demografi Desa Pengabean dan Desa Karanganyar

Desa Karaganyar dan Desa Pengabean merupakan desa yang termasuk dalam wilayah administrasi Kecamatan Dukuhturi Kabupaten Tegal.

Tabel 2. Jumlah Penduduk Desa

\begin{tabular}{ccc}
\hline \hline Desa & Jenis Kelamin & $\begin{array}{c}\text { Jumlah } \\
\text { (jiwa) }\end{array}$ \\
Karanganyar & Laki - Laki & 3187 \\
& Perempuan & 3320 \\
Pengaeban & Laki-Laki & 4055 \\
& Perempuan & 3856 \\
\hline \hline
\end{tabular}

Sumber : Profile Kecamatan Dukuhturi 2015

Desa yang memiliki kepadatan penduduk paling tinggi yaitu Desa Pengabean dengan rasio pertumbuhan $17,75 \%$ dibandingkan dengan Desa Karanganyar.

Tabel 3. Tingkat Pendidikan Desa

\begin{tabular}{|c|c|c|}
\hline $\begin{array}{c}\text { Tingkat } \\
\text { Pendidikan }\end{array}$ & $\begin{array}{c}\text { Desa } \\
\text { Pengabean }\end{array}$ & $\begin{array}{c}\text { Desa } \\
\text { Karanganyar }\end{array}$ \\
\hline SD & 767 & - \\
\hline SMP & 2552 & - \\
\hline SMA/SMK & 3878 & 2107 \\
\hline D1 & - & 25 \\
\hline D2 & - & 28 \\
\hline D3 & - & 27 \\
\hline S1 & 210 & 18 \\
\hline S2 & - & 7 \\
\hline
\end{tabular}

Sumber : Profile Kec. Dukuhturi 2015

Tingkat pendidikan sangat berpengaruh dalam proses pembangunan. Tentunya dalam Undang-Undang No. 6 Tahun 2014 tentang Desa, disebutkan bahwa minimal tingkat pendidikan seorang 
Jurnal Ilmu Pemerintahan: Kajian Ilmu Pemerintahan dan Politik Daerah, Vol. 3 (1), April 2018 - 6

Arif Zainudin ${ }^{1)}$, Sri Sutjiatmi ${ }^{2)}$

perangkat Desa yaitu SMA/SLTA atau sederajat.

Melihat tabel 2, menunjukkan bahwa di Desa Pengabean tingkat pendidikan terbanyak yaitu SMA/SLTA/sederajat dengan jumlah 47,64\%. Kemudian di Desa Karanganyar tingkat pendidikan terbanyak yaitu SMA/SLTA/Sederajat dengan jumlah $95,25 \%$.

Tingkat pendidikan ini sangat berpengaruh terhadap kualitas dokumen perencanaan. Semakin tinggi tingkat pendidikannya tingkat pemahaman terhadap partisipasi pembangunan masyarakat lebih baik.

\section{Model Perencanaan Pembangunan Desa}

Model perencanaan pembangunan Desa seperti dalam Pasal 80 ayat 1 Undang-Undang No. 6 Tahun 2014 tentang Desa, yaitu Perencanaan pembangunan Desa lebih mengutamakan pemberdayaan masyarakat dan Model Partisipatif dalam perencanaan pembangunan Desa. Implementasi pemberdayaan masyarakat Desa dengan cara melibatkan masyarakat dalam aktifitas pembangunan Desa dengan karakteristik dan ciri sebagai berikut :

a. Aspiratif, menampung masalah, usulan, kebutuhan, kepentingan, keinginan masyarakat.

b. Menarik, mendorong perhatian dan minat masyarakat desa untuk aktif dan terlibat dalam pembangunan.

c. Operasional, program yang dihasilkan dapat direalisasikan dalam kehidupan nyata sesuai sumber daya setempat dan mudah dalam penerapanya. d. Inovatif, program pembangunan yang dihasilkan mendorong kreativitas, perubahan serta mampu menjawab peluang dan tantangan masyarakat ke depan.

e. Partisipatif, melibatkan seluruh elemen masyarakat terutama bagi kelompok marjinal sebagai pelaku pembangunan.

f. Adaptif, menggunakan pendekatan dan metode yang sesuai dengan kondisi sosial adn budaya masyarakat setempat.

g. Koordinatif, memperkuat jalinan dan sinergitas stakeholders baik pemerintah, swasta, LSM, perguruan tinggi, masyarakat dan lembaga terkait lainnya dalam perencanaan pembangunan.

h. Demokratis, menghormati dan menghargai perbedaan pendapatan, terbuka menerima kritik musyawarah dan mufakat.

i. Edukatif, membangun masyarakat pembelajar melalui silang informasi, pengetahuan, pengalaman dan teknologi.

Adapun siklus dalam perencanaan pembangunan Desa terdiri dari 13 tahapan seperti terlihat dalam gambar 1.

Siklus perencanaan sesuai dengan gambar 2, dilakukan pada saat penyusunan RPJMDes, RKPDes, dan APBDes. Dalam tahapan 3, 7,9 dan 10 dilakukan dengan cara musyawarah Desa dengan melibatkan stakeholders Desa Karanganyar dan Desa Pengabean.

Ruang lingkup bidang Perencanaan Pembangunan Desa antara lain :

a. Birang penyelenggaraan Pemerintah Desa; 
Jurnal Ilmu Pemerintahan: Kajian Ilmu Pemerintahan dan Politik Daerah, Vol 3 (1), April 2018 - 7

Arif Zainudin ${ }^{1)}$, Sri Sutjiatmi ${ }^{2)}$
b. Pelaksanaan pembangunan Desa;
d. Pemberdayaan maysarakat Desa.
c. Pembinaan Kemasyarakatan Desa;

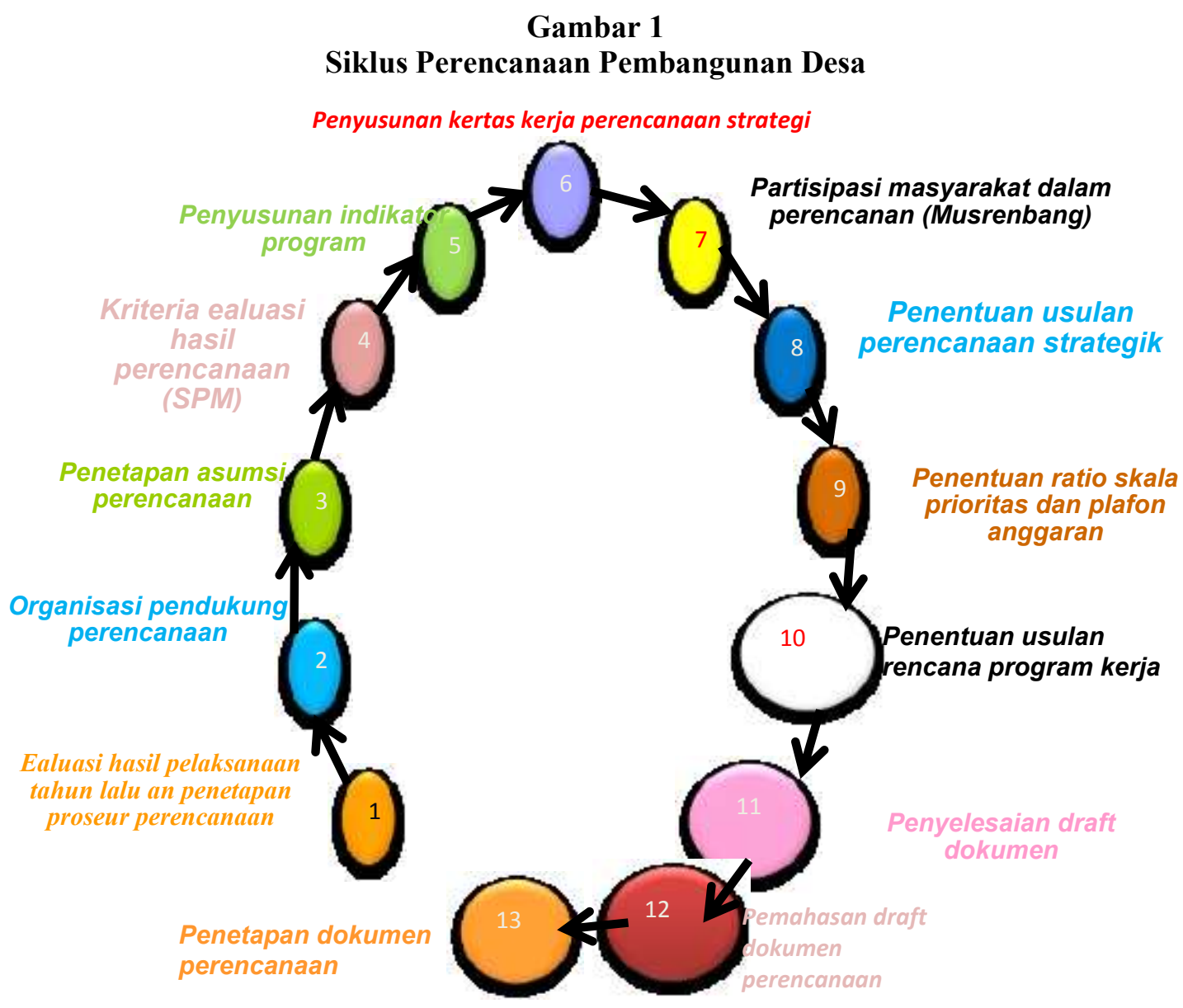

Copyright (C) 2018, JIP, ISSN: 2503-4685 (Print), ISSN: 2528-0724 (Online) 


\section{Penyusunan RPJM Desa}

Rencana Pembangunan Jangka Menengah Desa merupakan dokumen perencanaan pembangunan desa /kelurahan untuk periode 6 (enam) tahun yang memuat penjabaran dari visi, misi dan program kerja Kepala Desa yang penyusunanya berpedoman pada hasil musyawarah perencanaan pembangunan Desa RPJM Daerah (Kabupaten/kota), memuat arah kebijakan keuangan Desa, strategi pembangunan Desa, kebijakan umum, dan program satuan kerja.

Dokumen Rencana Pembangunan Jangka Menengah Desa (RPJM Desa) disusun berdasarkan pendekatan sebagai berikut :

1. Pemberdayaan, yaitu upaya untuk mewujudkan kemampuan dan kemandirian masyarakat dalam kehidupan bermasyarakat, berbangsa dan bernegara;

2. Partisipasif, yaitu keikutsertaan dan ketertiban masyarakat secara aktif dalam proses pembangunan;

3. Berpihak pada Masyarakat, yaitu seluruh proses pembangunan di Pedesaan secara serius memberikan kesempatan yang seluas-luasnya bagi masyarakat khususnya masyarakat miskin;

4. Terbuka, yaitu Proses tahapan perencanaan pembangunan dapat dilihat dan diketahui secara langsung oleh seluruh masyarakat desa;

5. Akuntabel, yaitu setiap proses dan tahapan-tahapan kegiatan pembangunan dapat dipertanggungjawabkan dengan benar, baik pada pemerintah di desa maupun pada masyarakat;

6. Selektif, yaitu semua masalah terseleksi dengan baik untuk mencapai hasil yang optimal;

7. Keberlanjutan, yaitu setiap proses dan tahapan kegiatan sesuai dengan potensi sumber daya alam dan sumber daya manusia yang tersedia;

8. Keberlanjutan, yaitu setiap proses dan tahapan kegiatan perencanaan harus berjalan secara berkelanjutan;

9. Cermat, yaitu data yang diperoleh cukup obyektif, teliti, dapat dipercaya, dan menampung aspirasi masyarakat;

10. Proses berulang, yaitu pengkajian ter-hadap suatu masalah/hal dilakukan secara berulang sehingga mendapatkan hasil yang terbaik; dan

11. Penggalian, yaitu didalam menemukan masalah dilakukan penggalian informasi melalui alat kajian keadaan desa dengan sumber informasi utama dari peserta musyawarah perencanaan.

Tahapan penyusunan Rencana Pembangunan Jangka Menengah Desa (RPJMDes) sebagai berikut :

a. MUSDUS, atau Musyawarah Dusun dilaksanakan dilingkup Dusun / RT/RW di desa guna menyerap aspirasi masyarakat dilingkup Dusun/RT/RW;

b. LOKAKARYA DESA, adalah rapat tekhnis ditingkat desa guna membahas dan mensinkronisasikan setiap usulan dari tingkat dusun / RT 
Jurnal Ilmu Pemerintahan: Kajian Ilmu Pemerintahan dan Politik Daerah,

Vol 3 (1), April 2018 - 9

Arif Zainudin ${ }^{1)}$, Sri Sutjiatmi ${ }^{2)}$

/ RW yang sudah masuk dari musayawarah Dusun yang telah dilakukan;

c. MUSRENBANGDES (Musyawarah Pembangunan Desa), adalah Musyawarah ditingkat Desa guna menjaring dan menentukan rencana pembangunan Desa yang sebelumnya sudah terjaring dalam musyawarah dusun dan tekah diujikan dilokakarya desa untuk kemudian ditetapkan dan ditindak lanjuti ditingkat yang lebih tinggi;

\section{Penyusunan RKP Desa}

Rencana Kerja Pembangunan Desa (RKPDes) adalah dokumen rencana pembangunan desa/kelurahan untuk periode 1 (satu) tahun sebagai penjabaran dari Rencana Pembangunan Jangka Menengah Desa (RPJMDes). RKP Desa memuat kebijakan prioritas program, dan kegiatan pembangunan desa baik yang dilaksanakan langsung oleh pemerintah Desa maupun yang ditempuh melalui partisipasi masyarakat.

Adapun langkah-langkah dalam penyusunan RKP Desa pertama, membentuk tim penyusunan RKP Desa yang teridir dari Kepala Desa selaku pembina, Sekertaris Desa sebagai ketua tim, Ketua lembaga pemberdayaan masyarakat sebagai sekertaris, dan anggota tim meliputi perangkat desa, lembaga pemberdayaan masyarakat, kader pemberdayaan masyarakat desa dan unsur masyarakat. jumlah anggota tim paling sedikit 7 (tujuh) orang dan paling banyak 11 (sebelas) orang kemudian mengutamakan keberimbangan gender atau harus mengikutsertakan perempuan. Pembentukan tim tersebut melalui rumusan musyawarah Desa disertai berita acara pembentukan Tim Penyusunan RKPDes.

Kedua, Pencermatan pagu indikatif Desa dan penyelarasan program/kegiatan masuk ke Desa. Kepala Desa mendapatkan informasi dari kabupaten/kota tentang pagu indikatif Desa dan rencana program / kegiatan Pemerintah, pemerintah Daerah provinsi dan pemerintah daerah kabupaten /kota yang masuk ke Desa.

Pada bulan Juli tahun berjalan tim sudah melakukan penyusunan draft rancangan RKP Desa dengan menggunakan format berikut ini.

Tabel 4. Format Penyusunan Program RKP Desa

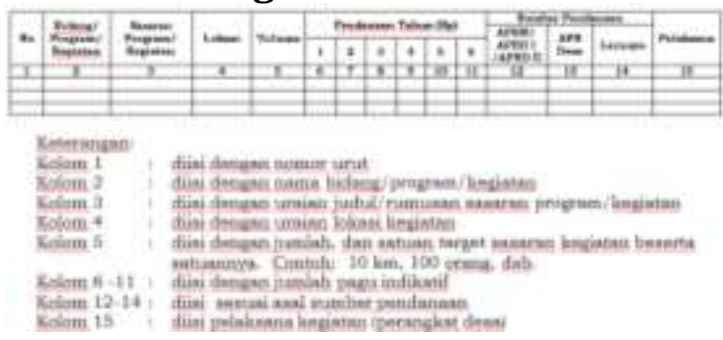

Tim penyusunan RKP Desa melakukan pencermatan pagu indikatif Desa yang meliputi :

a. Rencana dana Desa yang bersumber dari APBN;

b. Rencana alokasi dana desa (ADD) yang merupakan bagian dari dana perimbangan yang diterima kabupaten /kota;

c. Rencana bagian dari hasil pajak daerah dan retribusi daerah kabupaten/kota; 
Jurnal Ilmu Pemerintahan: Kajian Ilmu Pemerintahan dan Politik Daerah,

Vol. 3 (1), April 2018 - 10

Arif Zainudin ${ }^{1)}$, Sri Sutjiatmi 2)

d. Rencana bantuan keuangan dari APBD provinsi dan APBD kabupaten/kota.

Setelah melakukan pencermatan pagu indikatif berikutnya tim melakukan sing-kronisasi rencana program/kegiatan yang masuk ke desa dengan mencermati dokumen :

a. Rencana kerja pemerintah Kabupaten / Kota;

b. Rencana program dan kegiatan pemerintah, pemerintah daerah provinsi dan pemerintah daerah Kabupaten/Kota;

c. Hasil penjaringan aspirasi masyarakat oleh dewan perwakilan rakyat daerah Kabupaten /Kota.

Hasil telaah dituangkan dalam format pagu indikatif Desa dan pagu indikatif diseleraskan dengan kegiatan yang masuk ke Desa dan perencanaan program kerja Desa.

Setelah penyusunan pagu indikatif kemudian tim akan merancang draft RKP Desa yang akan dimusyawarahkan dalam perencana-an pembangunan Desa terkait dengan pe-nyusunan RKP Desa.

Musyawarah

pembangunan Desa diikuti oleh pemerintah Desa, Badan Permusyawaratan Desa, dan unsur masyarakat. Unsur masyarakat terdiri atas tokoh adat, agama, tokoh masyarakat, tokoh pendidikan, perwakilan kelompok tani, perwakilan kelompok nelayan, perwakilan kelompok perajin, perwakilan kelompok perempuan, perwakilan kelompok pemerhati dan perlindungan anak, dan perwakilan kelompok miskin.
Dalam musyawarah akan membahas rancangan awal RKP Desa yang berisikan tentang penyelenggaraan pemerintah Desa, pelaksanaan pembangunan, pembinaan kemasyarakatan dan pemberdayaan masyarakat Desa. Kegiatan musrenbangdes akan menentukan prioritas program dan kegiatan yang akan dijadikan program kerja Desa. Menentukan prioritas program / kegiatan berdasarkan dari penilian masyarakat setelah memetakan permasalahan Desa, dengan menggunakan tabel berikut ini.

\section{Tabel 5}

Tabel Penentuan Prioritas Program Desa

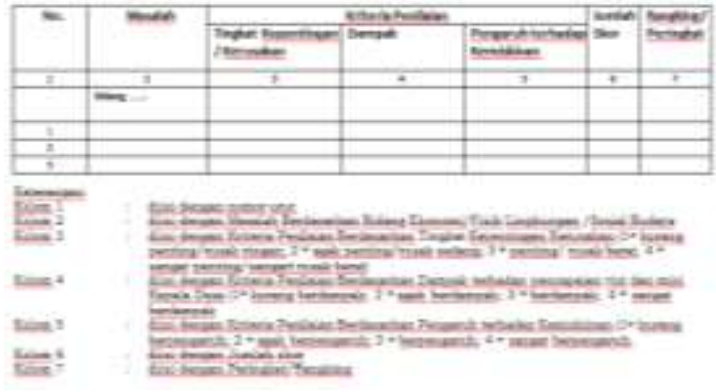

Setelah melakukan musrenbangdes dan telah disepakati hasil musyawarah maka keputusan tersebut melakukan penandatangan berita acara terkait penyusunan RKP Desa dan prioritas program kerja yang disepakati bersama.

Penetapan RKP Desa melalui musyawarah desa yang dihadiri oleh tim penyusun, perangkat desa, dan perwakilan dari tokoh masyarakat Desa. kemudian dibuatkan berita acara penetapan dan dilampiri daftar hadir anggota musyawarah Desa selanjutnya dijadikan Peraturan Desa. 
Jurnal Ilmu Pemerintahan: Kajian Ilmu Pemerintahan dan Politik Daerah,

Vol 3 (1), April 2018 - 11

Arif Zainudin ${ }^{1)}$, Sri Sutjiatmi ${ }^{2)}$

Kemudian setelah ditetapkan melalui Peraturan Desa, maka selanjutnya menyampaikan daftar usulan RKP Desa kepada Bupati / Walikota melalui camat. Penyampaian daftar usulan RKP Desa paling lambat 31 Desember tahun berjalan.

\section{Penyusunan APB Desa}

Anggaran Pendapatan dan Belanja Desa (APBDes) merupakan bagian integral dari proses perencanaan dan pengangaraan dimana, desa memiliki kewenangan untuk menyusun rencana keuangan tahunan pemerintahan desa yang dibahas dan disetujui bersama oleh Pemerintah Desa dan BPD yang ditetapkan dengan Peraturan Desa.

Dalam penyusunan Anggaran Pendapatan dan Belanja Desa (APBDes) didasarkan pada prinsip penyusunan, antara lain sebagai berikut.

a. Sesuai dengan kebutuhan penyelenggaraan pemerintah Desa berdasarkan urusan dan kewenanganyar;

b. Tepat waktu, sesuai dengan tahapan dan jadwal yang telah ditentukan peraturan perundangan-undangan;

c. Transparan, untuk memudahkan masyarakat mengetahui dan mendapatkan informasi yang seluasluasnya;

\section{Gambar 2}

Singkronisasi Dokumen Perencanaan

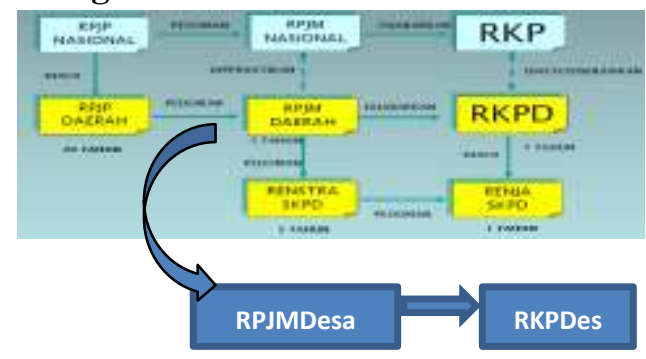

d. Partisipatif, dengan melibatkan masyarakat;

e. Memperhatikan asas keadilan dan kepatutan;

f. Tidak bertentangan dengan kepentingan umum, peraturan yang lebih tinggi dari peraturan Desa lainnya;

g. Semua penerimaan (baik dalam bentuk uang, maupun barang dan/atau jasa) dianggarkan dalam APBDesa;

h. Seluruh pendapatan dan belanja dianggarkan secara bruto;

i. Jumlah pendapatan merupakan perkiraan terukur dan dapat dicapai serta berdasarkan ketentuan perundang-undangan;

j. Penganggaran pengeluaran harus didukung dengan adanya kepastian ketersediaan penerimaan dalam cukup dan harus didukung dengan dasar hukum yang melandasinya.

Untuk penyusunan Anggaran Pendapatan dan Belanja Desa (APBDes) langkah dan tahapan mengikuti perumusan pada saat penyusunan Rencana Kerja Pemerintah Desa (RKPDes). Karena dalam penyusunannya anggaran merupakan bagian tidak terlepas dari bagian penyusunan kinerja pemerintah Desa.

\section{Gambar 3}

Siklus Penyusunan RKP Desa

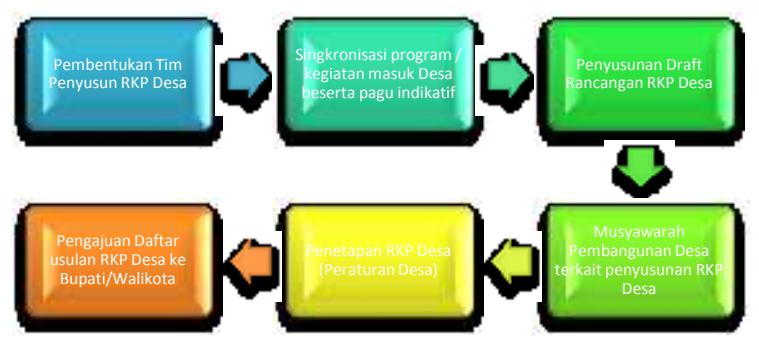


Jurnal Ilmu Pemerintahan: Kajian Ilmu Pemerintahan dan Politik Daerah,

Vol. 3 (1), April 2018 - 12

Arif Zainudin 1) *, Sri Sutjiatmi 2)

Anggaran Pendapatan dan Belanja Desa (APBDes) terdiri dari 2 (dua) bagian yakni Pertama, Pendapatan Desa dan Belanja Desa. Adapun Pendapatan Desa terdiri dari Pendapatan Asli Desa (PADes), Dana Transfer, dan pendapatan lainlainnya.

Kedua, Belanja Desa yang digunakan paling sedikit 70\% dari jumlah anggaran belanja Desa digunakan untuk mendanai penyelenggaraan Pemerintahan Desa, Pelaksanaan Pembangunan Desa, pembinaan kemasyarakatan Desa, dan pemberdayaan masyarakat Desa. kemudian $30 \%$ dari jumlah anggaran belanja Desa digunakan untuk penghasilan tetap dan tunjangan Kepala Desa dan perangkat Desa, operasional pemerintah Desa, tunjangan dan operasional Badan Permusyawaratan Desa dan insentif rukun tetangga dan rukun warga.

Desa Pengabean dan Desa Karagannyar merupakan Desa yang menerima Dana Desa dan Alokasi Dana Desa adapun jumlah pendapatan kedua Desa tersebut dapat dilihat pada tabel 6 berikut ini.

\section{Tabel 6}

Pendapatan Desa Pengabean dan Desa Karanganyar

\begin{tabular}{lcc}
\hline \hline \multicolumn{1}{c}{ Desa } & $\begin{array}{c}\text { Pendapatan } \\
\text { (Rp) }\end{array}$ & $\begin{array}{c}\text { Pengeluaran } \\
\text { (Rp) }\end{array}$ \\
Pengabean & 1.227 .491 .273 & 1.302 .029 .520 \\
Karanganyar & 1.268 .767 .192 & 1.305 .651 .896 \\
\hline \hline
\end{tabular}

Berdasarkan dari tabel 6, menunjukkan bahwa pengeluaran kedua desa tersebut, lebih besar dari pendapatan yang diterima Desa. Oleh karena itu, dalam perencanaan anggaran lebih mengutamakan prioritas program kerja yang sangat diperlukan oleh masyarakat Desa.

\section{SIMPULAN DAN SARAN}

\section{Simpulan}

Berdasarkan hasil pembahasan yang telah diuraikan bahwa, perencanaan pembangunan Desa Pengabean dan Desa Karanganyar lebih mengutamakan pemberdayaan masyarakat dan partisipasi masyarakat Desa.

Pemberdayaan masyarakat Desa digunakan untuk memanfaatkan sumber daya yang dimiliki oleh Desa agar pemertaan ekonomi dapat terwujud dan menciptakan kemandirian Desa.

Model partisipasi yang digunakan oleh Desa Karanganyar dan Desa Pengabean dalam perencanaan pembangunan Desa dengan melibatkan masyarakat Desa dalam kegiatan musyawarah perencanaan pembangunan Desa. Musyawarah tersebut pada penentuan program kerja atau prioritas kegiatan Desa dan penentuan kebijakan anggaran.

\section{Saran}

Dengan melakukan pengabdian kepada masyarakat merupakan bentuk kepedulian terhadap penyelesaian permasalahan masyarakat. Kegiatan workshop dan bimbingan teknis terkait penyusunan dokumen perencanaan pembangunan Desa adalah bentuk solusi terhadap permasalahan pemerintah Desa pasca diterapkannya Undang-Undang No. 6 Tahun 2014 tentang Desa.

Oleh karena itu untuk pemerataan perekonomian ditingkat masyarakat Desa perlu dilakukan aktivitas serupa dengan melibatkan beberapa Desa. Peran serta Perguruan Tinggi sangat berpengaruh dalam kesempurnaan kebijakan yang diterapkan oleh pemerintah. 
Jurnal Ilmu Pemerintahan: Kajian Ilmu Pemerintahan dan Politik Daerah,

Vol 3 (1), April 2018 - 13

Arif Zainudin ${ }^{1)}$, Sri Sutjiatmi ${ }^{2)}$

\section{DAFTAR PUSTAKA}

Arnstein, S. R. (1969). A Leader Citizen

Participation. Retrieved from

http://lithgow-schmidt.dk/sherry-

arnstein/ladder-of-citizen-

participation.html

Bachrein, S. (2016). Pendekatan Desa

Membangun di Jawa Barat: Strategi dan

Kebijakan Pembangunan Perdesaan.

Analisis Kebijakan Pertanian, 8(2), 133.

https://doi.org/10.21082/akp.v8n2.2010.1 33-149

Deviyanti, D. (2013). Studi tentang Partisipasi Masyarakat dalam Pembangunan di Kelurahan Karang Jati Kecamatan Balikpapan Tengah. Ejournal.an.fisipUnmul.ac.id, 1(2), 380-394. Retrieved from http://www.ejournal.an.fisipunmul.ac.id/site/wpcontent/uploads/2013/05/JURNAL DEA (05-24-13-09-02-30).pdf

Fauzi, N., \& Zakaria, R. (2000). Mensiasati otonomi daerah: panduan fasilitasi pengakuan dan pemulihan hak-hak rakyat. Retrieved from https://scholar.google.co.id/scholar?hl=id \&as_sdt $=0 \% 2 \mathrm{C} 5 \& \mathrm{q}=$ Mensiasati + Otonom i+Daerah\%3A+Panduan++Fasilitasi+Pen gakuan+dan+Pemulihan+HakHak+Rakyat.+YogyakartaINSIST+Press.\&btnG $=$

Fogg, C. (1994). Team-based strategic planning: A complete guide to structuring, facilitating, and implementing the process. Retrieved from https://www.google.com/books?hl=id\&lr $=\& \mathrm{id}=3 \mathrm{SXTSFdCyRIC \& oi}=$ fnd\&pg $=\mathrm{PR}$ $8 \& \mathrm{dq}=$ Team + Based + Strategic + Planning, $+\mathrm{A}+$ Complete + Guide + to + Stucturing, $+\mathrm{Fa}$ cilitating+and+Implementating + the + Proc ess. + New + York $+:+$ AMACOM\&ots $=p H$ MYAYbb-_\&sig=tKocUXfqAyfnr5iVAZXICgAQRc

Hadi, Hakim, A., \& Noor, I. (2014). Wacana. WACANA, Jurnal Sosial dan Humaniora (Vol. 17). Retrieved from http://www.wacana.ub.ac.id/index.php/w acana/article/view/290

Hilman, Y. A. (2017). Strategi pembangunan pariwisata internasional berbasis pertanian organik "shining batu." ARISTO, 5(1), 82-100.

https://doi.org/10.24269/ARS.V5I1.402

Mayasari, L. (2014). Pengaruh Pertumbuhan Ekonomi, Pendapatan Asli Daerah dan

Dana Alokasi Umum terhadap Pengalokasian Anggaran Belanja Modal pada Pemerintah.

Ejournal.undiksha.ac.id, 2(1), 1-11.

Retrieved from http://ejournal.undiksha.ac.id/index.php/S 1ak/article/download/4394/3393

Narutomo, T. (2014). Program Penguatan Sistem Inovasi Daerah (SIDa) sebagai Exit Strategy Program Nasional Pemberdayaan Masyarakat (PNPM). Binaprajajournal.com, 6(2), 143-156. Retrieved from http://binaprajajournal.com/ojs/index.php/ $\mathrm{jbp} /$ article/view/49

Nugroho. (2010). MODEL EKONOMI BASIS UNTUK PERENCANAAN PEMBANGUNAN DAERAH. Jurnal Dinamika Pembangunan, 1(1), 23-30. Retrieved from http://eprints.undip.ac.id/13968/1/Model Ekonomi_Basis_Untuk_Perencanaan....by _Nugroho_sBM_(OK).p.pdf

Planners, S. A. (1969). A ladder of citizen participation. Taylor \& Francis.

Retrieved from http://www.tandfonline.com/doi/abs/10.1 080/01944366908977225

Raharjana, D. T. (2012). MEMBANGUN PARIWISATA BERSAMA RAKYAT: KAJIAN PARTISIPASI LOKAL DALAM MEMBANGUN DESA WISATA DI DIENG PLATEAU. Jurnal Kawistara (Vol. 2). Universitas Gadjah Mada. Retrieved from https://journal.ugm.ac.id/kawistara/article /view/3935/3216

Rustiadi, E., Saefulhakim, S., \& Panuju, D. (2009). Perencanaan dan pengembangan wilayah. Retrieved from https://www.google.com/books?hl=id\&lr $=\& \mathrm{id}=\mathrm{vW} 6 \mathrm{rDAAAQBAJ} \& \mathrm{oi}=\mathrm{fnd} \& \mathrm{pg}=\mathrm{P}$ $\mathrm{T} 1 \& \mathrm{dq}=$ sistem + perencanaan + pembangun an+nasional\&ots=Z3SaWuq_gY\&sig=A18bhuwUMEqlRMwwaLvGIFH_sU 


\section{Jurnal Ilmu Pemerintahan: Kajian Ilmu Pemerintahan dan Politik Daerah, Vol. 3 (1), April 2018 - 14}

Arif Zainudin ${ }^{1)}$, Sri Sutjiatmi 2)

Sugiyono, D. (2009). Metode Penelitian. Digilib.unila.ac.id. Retrieved from http://digilib.unila.ac.id/6579/17/BAB III.pdf

Sumenge, A. (2013). Analisis Efektifitas dan Efisiensi Pelaksanaan Anggaran Belanja Badan Perencanaan Pembangunan Daerah (Bappeda) Minahasa Selatan. Ejournal.unsrat.ac.id, 1(3), 74-81. Retrieved from https://ejournal.unsrat.ac.id/index.php/em ba/article/view/1941

Zainudin, A. (2016). Model Kelembagaan Pemerintahan Desa. Jurnal Ilmu Pemerintahan : Kajian Ilmu Pemerintahan Dan Politik Daerah, 1(2), 332. https://doi.org/10.24905/jip.v1i2.607 Zakaria, F., \& Suprihardjo, R. (2014). Konsep Pengembangan Kawasan Desa Wisata di Desa Bandungan Kecamatan Pakong
Kabupaten Pamekasan. Ejurnal.its.ac.id, 3(1), 245-249. Retrieved from http://www.ejurnal.its.ac.id/index.php/tek nik/article/view/7292

\section{PROFIL SINGKAT}

Arif Zainudin,S.IP.,MA merupakan dosen program studi ilmu pemerintahan Universitas Pancasakti Tegal. Perencanaan pembangunan dan Tata kelola pemerintahan merupakan bidang keahlian. Selain menjadi dosen, merupakan konsultan pemerintahan bidang perencanaan pembangunan dan tata kelola pemerintahan.

Dra. Sri Sutjiatmi, M.Si, merupakan dosen program studi ilmu pemerintahan Universitas Pancasakti Tegal. Fokus kajian ialah tata kelola sumber daya manusia dan etika pemerintahan. 